Hanna Dziakowska, Mirosław Grochowski

\title{
CHANGES IN WARSAW'S SPACE IN THE CITY'S RESIDENTS PERCEPTION
}

\section{INTRODUCTION}

The goal of this article is to answer the question how changes in the urban space of the city of Warsaw, that result from systemic changes in spheres of politics and economy, are perceived by the city's inhabitants. The article also briefly presents contemporary trends in urban development of metropolitan city in a transition period characterized by development of new rules that govern a game for city's space and by appearance of new agents, which play an important role in shaping the new urban reality. The article is based on results of a survey conducted in Warsaw in January 1997. 220 questionnaires, out of 300 administered, were used for the analysis of perception of Warsaw's urban space changes.

\section{TRANSFORMATION OF WARSAW'S URBAN SPACE}

Warsaw is experiencing many changes that have been brought about by market economy mechanisms and new ways of managing the city resulting from the fact that actors who influence the city's space have become more proactive. Additionally, among actors influencing the city's space, there are new ones like local governments (Warsaw is divided into 11 gminas municipalities, which form an obligatory municipal association; gmina Centrum is additionally divided into seven districts: Mokotów, Ochota, Praga Południe, Praga Północ, Śródmieście, Wola, Żoliborz) (see Map 1), organizations of former real estate owners who are now claiming their properties, interest groups representing domestic and foreign capital, professional groups, as well as organizations of local communities. All these groups exercise new democratic rules by articulating and advocating their particular interests on different public fora. Actions undertaken by them have direct or indirect impact on processes that shape urban space.

Warsaw's spatial layout was designed after World War II. Elements of pre-war Warsaw are visible in this layout, however they are dominated by 
an ideologically-driven strategy of spatial development and land use plans. After the changes of 1989 the role of industry in the city's development has been questioned. The first years of the new decade were marked by development of the service sector. Contemporary Warsaw is becoming more and more attractive for foreign firms that look for well qualified employees and for office space. The rising attractiveness of Warsaw is reflected in its landscape. New buildings offering office space have become characteristic landmarks and indicators of ongoing changes. Warsaw's space is acquiring a new quality of a place that offers new social and economic opportunities (Bielecki, 1996).

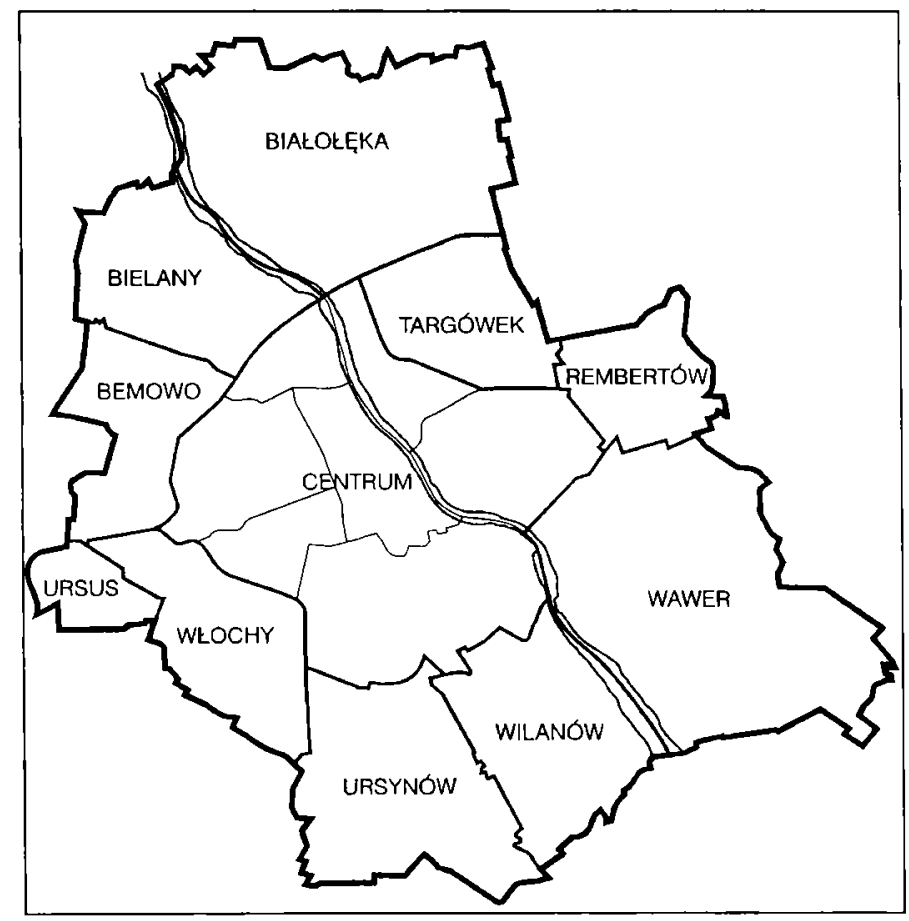

Map 1. Administrative division of Warsaw.

The primary and fundamental reason for changes that occur in Warsaw is a complex process of transformation of Polish economy and society. This process shapes new conditions for economic development and influences the role of different levels of governance in the development process. Intergovernmental relations and dynamic links between all other actors competing for urban space create a framework where consensus on future development and organization of space should be reached. Local governments have to search for new coalition partners such as business elites, established interest organizations and voluntary associations. The city's space is being 
changed due to pressure from more powerful and influential actors. The changes take form of planned and controlled processes as well as spontaneous activities that bring chaos and disorder to the city.

Although transformation in being experienced by almost all parts of Warsaw, there is no balance in terms of location and intensity of new phenomena in the city's space. The most spectacular and visible changes take place in the central part of Warsaw (the gmina of Centrum) and several "nodes" in surrounding gminas. It should also be mentioned that there are several gminas around Warsaw that undergo dynamic changes having located in their areas services for Warsaw inhabitants. Less visible changes in the city's landscape take place in big, relatively new housing developments and parts of Warsaw rebuilt or built just after the war.

\section{PERCEPTION OF CHANGES IN WARSAW'S SPACE}

The three general themes that respondents were asked about were: preferences concerning place of residence in the city of Warsaw area and characteristic features of selected districts; characteristic features of the central part of Warsaw and characteristic objects/building/elements of cultural landscape of the central part of Warsaw. Respondents were asked to identify attractiveness of specific areas in Warsaw using a set of positive and negative characteristic features. Among positive characteristic features mentioned most often by respondents were: good transportation, a lot of green spaces, calm, clean, quite, safe. Among negative characteristic features the most often mentioned were: poor transportation, lack of green spaces, noisy, peripheral, bad, dirty, not safe (Fig. 1).

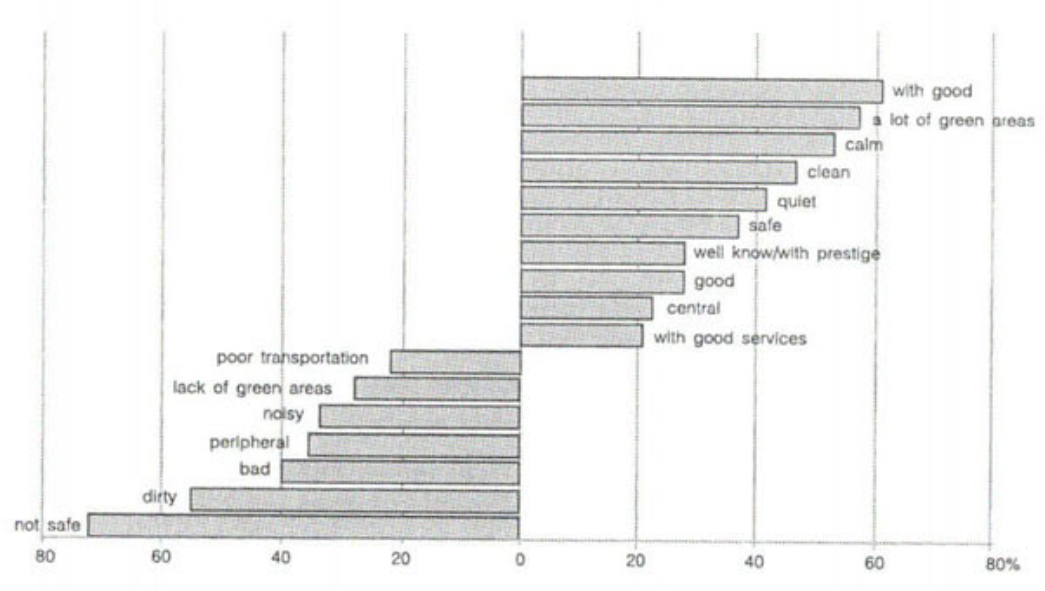

Fig. 1. Characteristic features of gminas that respondents would like/would not like to live in. 
Result of the analysis of attractiveness of specific Warsaw's gminas and districts assessed by citizens indicate, that although stereotypes or traditional judgements still exist, changes in Warsaw's space modify the image of the city. Some parts of Warsaw are perceived in the same way as they were several years ago; some, especially those which experienced spectacular transformation, are perceived as much better. The best examples of lack of changes in residents' perception is the district of Mokotów in the gmina of Centrum (Fig. 2). Respondents perceived Mokotów as the most attractive part of Warsaw. This part of Warsaw was relatively little destroyed during World War II and has retained its pre-war architecture, style and atmosphere. The district of Mokotów can be characterized as a prestigious neighborhood, although not the whole district consists of residential areas with detached and semi- detached houses. The common perception is that Mokotów is not very densely populated and with the landscape similar to peaceful suburbs. Even parts of Mokotów with apartment houses have a "human scale" since the buildings are three or four stories high. Mokotów, especially its older part, compared to other gminas of Warsaw (even to other districts within gmina Centrum) seems to have a pretty clear spatial structure with Puławska Street - the main street of the district and one of Warsaw's main thoroughfares - which is the axis organizing its structure. Stores, shops, services centers including theaters and movie theaters are located along Puławska Street. This street attracts Warsaw's residents not only people who live in this district of the Centrum gmina. It might be assumed that Mokotów is also attractive for respondents because the first subway line connects it with the downtown and suburbs which are popular recreation destinations.

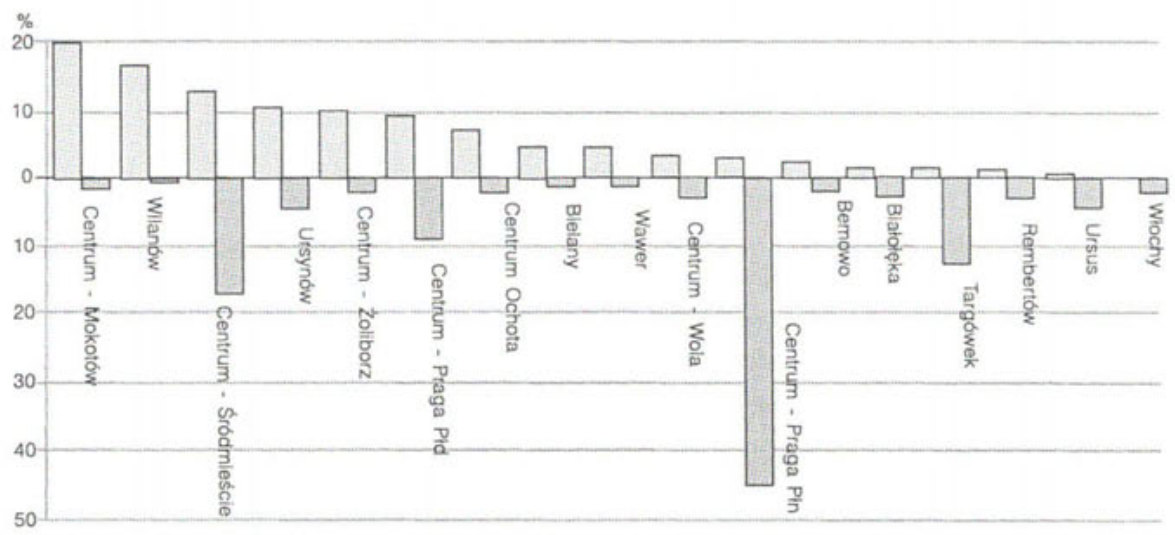

Fig. 2. Gminas of Warsaw that respondents would like / would not like to live in.

The second most attractive area in Warsaw is the gmina of Wilanów - a gmina located on the outskirts of the city. In this case residents' perception is entirely different. Gmina Wilanów was established in 1994 after Warsaw 
administrative structure reform. At the end of 1980s Wilanów was definitely less popular among Warsaw's inhabitants and was ranked as one of the last areas that respondents wanted to live in. The status of the gmina of Wilanów and its perception have changed dramatically. Since the beginning of 1990s Wilanów has been very popular and fashionable place to live in or just to visit. Luxury detached housing estates have been developed during last three or four years in Wilanów boosting its status. The prestige of Wilanów is still growing even more because of the famous and wealthy people who reside there. Wilanów is also very popular among foreigners who work in Warsaw and rent houses in this gmina.

The central part of Warsaw (defined as the gmina of Centrum) is being perceived in various ways. Most opinions are negative, however the very center - district Śródmieście (downtown) - is the third on the list of attractive places to live in. Compared to a similar study conducted ten years ago, the number of people who perceive the center as less attractive place is much larger. This is probably because the downtown area is not any longer a place where most services are located.

The gmina of Ursynów is the part of Warsaw definitely ranked now much higher than in the past. Ursynów is a typical new housing estate from the communist period. Negative features of Ursynów listed by Warsaw inhabitants in the 1980 s were: the very specific character of the district that was predominantly "bedroom community" not a place to live, quality of buildings and apartments, lack of basic services, poor communication with the central part of Warsaw and other districts (Libura, 1992). These days all negative features listed above are much less cumbersome for Ursynów inhabitants. The new subway line significantly improved access to the central part of Warsaw. Foreign chains of big retail stores and supermarkets like Leclerc, Geant or Globi provide necessary services of good quality. New building represent a new style in architecture and change the monotonous and depressing landscape of grey concrete blocks of flats.

A part of Warsaw that is losing popularity is the district of Żoliborz in the Centrum gmina. Żoliborz used to be at the very top in rankings done in the 1980s. Since 1990 no new big investments in service infrastructure have taken place in this part of Warsaw. As a result, Żoliborz, without losing its objective advantages (respondents still list the same positive features of this district: a quiet, safe, and friendly area with well-developed services), lost in perception of Warsaw residents.

The district of Praga Południe in the Centrum gmina is an example of ambivalent perception that results from the very distinctive spatial structure of the district. Praga Poludnie consists of two parts: there is an island of Saska Kępa in it - an area similar to the old part of Mokotów, which is perceived in a very positive way, and the rest of Praga that is perceived negatively.

The list and image of gminas and areas that Warsaw's inhabitants do not definitely want to live in are basically the same as they were in the 
1980s. It seems that the list and image are being shaped by deeply rooted stereotypes. Gminas: Centrum - Praga Północ and Targówek are still among the "bad" areas. Also new gminas established in 1994 like Włochy, Ursus, Rembertów or Białołęka were evaluated as poor. It seems that the geographical location and lack of information about these gminas contributes to the general opinion about how attractive the area is.

The only area that Warsaw inhabitants identify themselves with as citizens of this city is the central part of Warsaw understood as the district of Śródmieście in the Centrum gmina. Traditionally, people find this part of the city familiar and well-defined in terms of location and functions. It confirms the opinion that the only area that people recognize and think of as their own is the central part of the city saturated with symbols and unique political and cultural functions (Wallis, 1979). In the case of Warsaw the term: "city of Warsaw - Warsaw" is being identified with the relatively small central part of the city where most historical buildings (also those from the communist era) are located.

An analysis of answers concerning symbols of Warsaw brought very interesting results. The most popular symbol of the city is the Palace of Culture (Fig. 3). The Palace located in the very center dominates the city's landscape. This unique landmark - product of the communist era - helps people locate themselves in Warsaw's space and is perceived as a very stable element of the city's morphology ( Zielińska, 1995). It might be assumed that the special role of the Palace of Culture in common perception results from the fact that for years the Palace has played very instrumental functions because of its facilities for cultural, educational, commercial, and sport activities.

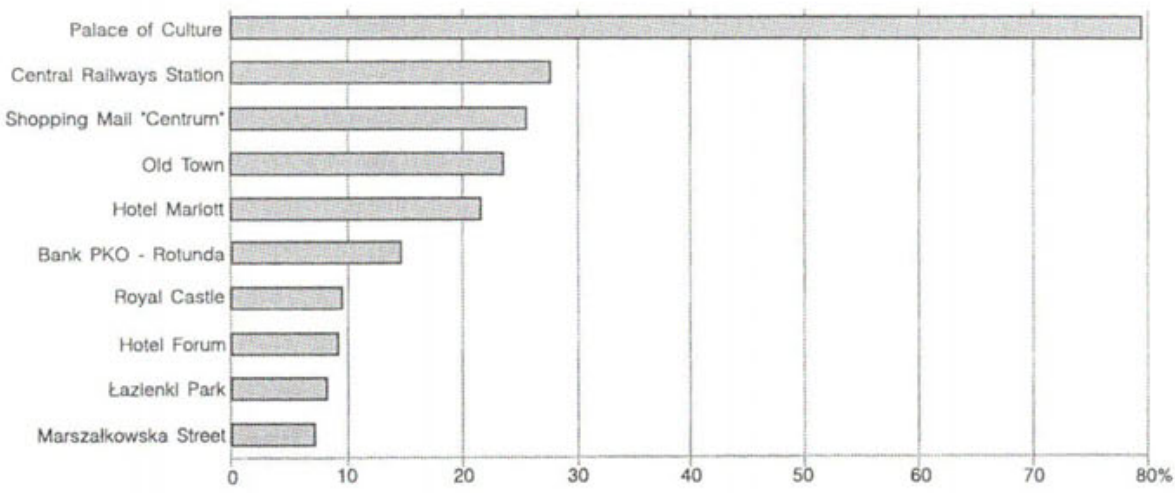

Fig. 3. Characteristic places /buildings/ objects that are identified with the central part of Warsaw.

The Central Railway Station located in the vicinity of the Palace of Culture is another popular symbol of Warsaw. The Station is not just a station and important transportation node in Warsaw. It is also an unique shopping center located in underpasses around the station. The area is 
popular among visitors as well as Warsaw's residents. Other very popular buildings, sites or places that are associated with Warsaw and perceived as its symbols are: the "Centrum" Shopping Mall, The Rotunda PKO Bank and Old Town. Respondents located also two hotels: Forum and Marriott (both situated in the district of Śródmieście) in this group. These two hotels were the first skyscrapers built in the central part of Warsaw. Although these two hotels do not perform any specific functions for an average Warsaw inhabitant, they are very popular and well-known elements of Warsaw's landscape.

\section{CONCLUSIONS}

Comparison of results of the survey conducted in January 1997 with results of a survey in the previous decade shows that in citizens' perception traditionally "bad" areas are still "bad". It concerns especially gminas and districts located on the right side of the Vistula River.

It is characteristic that most respondents did not mention any newly created buildings offering office spaces in Warsaw's downtown as symbols or things that could be identified with Warsaw. Theses buildings represent modern architecture, are easily visible in Warsaw's landscape, however, they are too new and have not been "named" by citizens just for themselves yet so they do not exist on the "mental map".

The perception of changes in Warsaw's space indicates that the spatial structure of the city is deeply rooted in people's mind. It might be also stated that citizens see and/or are aware best of changes that take place in the most popular parts of the city (or the most often visited because of the concentration of many functions in this area). The changes of the city's space are not perceived as especially important or positive if they do not directly influence the quality of residents' life.

\section{REFERENCES}

Bielecki Cz., 1996, Gra $w$ miasto (The Game Called City), Fundacja Dom Dostępny, Warszawa.

Libura H., 1990, Percepcja przestrzeni miejskiej (Perception of Urban Space); seria: Rozwój regionalny- rozwój lokalny-samorząd terytorialny (series: Regional Development-Local Development-Territorial Self Government), 31, European Institute for Local and Regional Development, University of Warsaw.

Królik ow ski J.T., 1996, Druga Warszawa, czyli pomiędzy socrealizmem a postmodernizmem (The Second Warsaw: Between Socrealism and Postmodernism); in: Oblicza Warszawy (Images of Warsaw), Arche 13/14, Warszawa.

W a 1 lis A., 1979, Informacja $i$ gwar (Information and Buzz), PWN, Warszawa.

Zi elińska M., 1995, Warszawa - dziwne miasto (Warsaw - The Strange City), Instytut Badań Literackich PAN, Warszawa. 
